\title{
The Aesthetics of Literary Transculturation: The Latvian Case
}

\author{
BENEDIKTS KALNAČS
}

\begin{abstract}
This paper offers an interpretation of Rūdolfs Blaumanis' novella Andriksons (1898) that is based on three intellectual positions. (1) The insight gained by postcolonial criticism that the political and economic division of the world as created by colonial relationships and secured by a consciously shaped system of ideological models has left a lasting impression on the psychology of both the representatives of the superpowers and the local inhabitants of the colonized territories. The main thread of analysis is to research how the opinions of two characters and the differences in their worldviews meet in Blaumanis' text, and to reveal how the colonial and anti-colonial viewpoints are expressed in such confrontations. (2) Since Blaumanis' novella was written at the end of the $19^{\text {th }}$ century, which was one of the most intensive periods of Latvian nation-building, the anti-colonial discourse is closely related to the manifestation of nationalism in art. Nationalism, or any ideology, is most powerful in a work of art when it is outwardly unnoticeable, but inwardly capacious and expressed as a potentiality; therefore, the poetics of the text are important in this paper. (3) The framework of my argument is provided by current debates on the so-called "decolonial turn" which also involves concepts of modernity, coloniality and decoloniality. Therefore, the strategic aim of this research can be described as an effort to trace colonial contexts and decolonial options of modern Baltic cultures in global perspective.
\end{abstract}

Keywords: postcolonial theory, colonial and anti-colonial discourse, modernity, coloniality, decolonial option, Baltic literature, Latvian literature, Rūdolfs Blaumanis

DOI: http://dx.doi.org/10.12697/IL.2013.18.1.04

In this paper I focus on the novella "Andriksons" written in 1898 by the Latvian writer Rūdolfs Blaumanis, ${ }^{1}$ but the larger framework of this contribution is provided by an attempt to have a say in the debate on modernity/coloniality/decoloniality which has recently surfaced as a topical issue in postcolonial

1 I have already dealt with some aspects of this text in Latvian in the paper titled Rüdolfa Blaumaņa novele "Andriksons": postkoloniāls lasijums (Kalnačs 2011). 
studies. I also want to single out current theories of the Latin American branch of subaltern studies as the trend in contemporary scholarly discourse to which I come closest in this paper.

Let me begin with the obvious. In the scholarly field of postcolonial studies, there is a growing diversity in terms of time and space, cultures, territories, and languages involved. Alongside English and British Commonwealth history, other cultural milieus and languages like French, Spanish and German reappear as forums for discussions linked to the empires which were created and administrated by using the respective language tools. Postcolonial studies also tend to deal with more indigenous cultures and languages.

So perhaps it is not that surprising that my research interests are linked to late $19^{\text {th }}$ century realities in an area which normally does not receive the focus of postcolonial studies - the Baltic countries, more specifically, the territory of today's Latvia and Estonia. Since the $13^{\text {th }}$ century the lands on the Eastern Baltic shores have been under the influence of German settlers, and later they became part of the Russian empire for about two centuries (while German cultural and social influence was to a great extent preserved). So my aim is to make the case for potential relevance of a seemingly peripheral literary culture - in this instance Latvian - to more global issues.

The framework of my argument is provided by current debates on the socalled decolonial turn which also involves concepts of modernity, coloniality and decoloniality. Especially relevant for my considerations is the concept of colonial difference (elaborated most persuasively by Walter Mignolo), based on the assumption that there is a common source of modernity and coloniality. Both phenomena were brought about by the late $15^{\text {th }}$ century discovery and conquest of America which provided the basis for the construction of an European identity created in opposition to that of the newly exposed 'others'. It promoted European superiority as a justification for the intervention. The European identity formation then took a new turn during the age of Enlightenment by reaffirming the intellectual superiority of the European mind and bringing about the ideology of the more progressive position Europeans took both on the developmental time scale as well as in terms of the new planetary consciousness. The Enlightenment thus also provided for a retrospective opportunity to interpret in a new light the discovery of America and other discoveries/conquests, including those taking place at the margins of Europe. The ideological concepts and implications of the Enlightenment cleared the ground for the so-called modern world system (theoretically elaborated by Immanuel Wallerstein, among others) which remained virtually unchallenged until the gradual rise of decolonial thinking. For these reasons, the colonial matrix of 
KALNAČS

power in the Baltic area comes so close to that which is characteristic of other colonized parts of the world.

The strategic aim of my research can be described as an effort to trace colonial contexts and decolonial options of modern Baltic cultures in global perspective. In this paper I focus on a literary text, the novella "Andriksons" written in 1898 by Rūdolfs Blaumanis, one of the most important Latvian authors of the turn of the century period. I will first provide a short summary of Blaumanis' plot, followed by a discussion of its elaboration, and will also continue with some theoretical reflections, dealing in particular with a brief exposition of the relevance of the theoretical concepts of 'delinking' and 'decoloniality' at the beginning of the $21^{\text {st }}$ century.

So, first, what does the novella tell us? It depicts a meeting of two men, a landlord and a farmer. The native farmer has come to the Baltic German manor in order to explain to his master why he has cut down trees standing on his farm's land without asking the landlord's permission. (From the psychological point of view, it is important to add that this is their first meeting - the landlord has recently returned from abroad and taken over his deceased father's farm; the farmer has inherited his a couple of years previously.) The two men quarrel on the matter, and, as the farmer leaves the manor, in an act of revenge he sets fire to the surrounding pine forest. As an afterthought, however, the farmer regrets his deed and tries to smother the flames, while at the same time it comes to light that his children were playing in the forest and have not returned home. At the end of the novella, the flames are brought under control, and it is the landlord who has met the farmer's children, now being reunited with their father. The farmer's regret finds expression in the presumed acknowledgement of his deed, even if the novella stops just short of this point.

If we take the next step, what are the signifiers here and what is being signified? First, the meeting of the two men signifies exactly what it is about, an encounter of two people who are to a certain extent similar to each other but differ considerably in their character and, significantly, in their social status. The attempted logic of the farmer is best revealed in his argument that he has cut down the trees because he considers them to be inherited from his father as deliberately preserved at an earlier stage when the making of a clearing was permitted. And, as he explains to the landlord, 'what I inherited from my father is mine, as what you inherited from your father is yours' (Blaumanis 1958: 315). In an attempt to overcome differences, the supposed link between the farmer and the landlord is at the centre of the argument.

The landlord, to a certain extent, acknowledges the mutual link. At the same time, their respective backgrounds inevitably suggest the impossibility of coming to terms with this issue. The ancestors of the landlord did write down 
the rules which the ancestors of the farmer were supposed to follow, be it during the period of serfdom or, as in this case, during its aftermath. Even if the psychological portrayal of the encounter is subtle, there is no exception to the rule. Thus the attempt to link the experience of two people is shattered by the immobility of the borders constructed between them.

Interestingly enough, however, the novella becomes most fascinating exactly at the point where it makes the link between the landlord and the farmer deeply problematic and existentially uncertain. The image of fire, dominating the latter part of the text, thus simultaneously provides us with a sign as well as with a second level signifier. In order to provide a clue let me return to the concept of 'colonial difference', which implies not only the delinking of the two men but also that of the discourse each of them represents.

The notion of 'discourse' points towards Michel Foucault and Edward Said, among others. Here we recall issues dealing with power relations among different strata of society and, even more so, with competing representations of self and other - characteristic of colonial societies. But let me involve Walter Mignolo. In his 2011 book The Darker Side of Western Modernity: Global Futures, Decolonial Options, Mignolo has this to say about the important concepts of modernity and coloniality:

I learned that hidden behind modernity was the agenda of coloniality; that coloniality was constitutive of modernity; that coloniality was the secret shame of the [Western] family, kept in the attic, out of the view of friends and family. Thus, the slash (“/”) between, which both unites and divides modernity and coloniality (modernity/coloniality), was an invisible dwelling place, the place of divide between humanitas [those allowed to have their own discourses]/anthropos [those not allowed to]. (Mignolo 2011: xxi)

To name and unveil the hidden geo- and body-politics of the Western code is already a decolonial move that legitimizes, at the same time, geo-historical locations and bio-graphic stories that were delegitimized and pushed on the side or outside of the house of knowledge. (Mignolo 2011: xxii-xxiii)

In his detailed discussion of different options to overcome the dominance of the Western 'house of knowledge', Mignolo singles out the concept of decoloniality which has become 'an epistemic and political project' (Mignolo 2011: $\mathrm{xxv}$ ).

Now back to the novella. In the context of the above observations, the overarching theme of Blaumanis' text, for me, is the substantial necessity and, at the same instant, extreme difficulty of the decolonial move, of epistemic 
KALNAČS

disobedience and delinking, embodied in the trajectory of the farmer's inner transformations during the course of the novella.

Let us take a closer look at this trajectory. At the beginning of the novella, the farmer, Andriksons (indeed, he has a name) rather self-consciously enters the conversation with the landlord as a participant in an Enlightenment-like rational discourse. On his way to the manor (taking place, we might be willing to say, offstage), Andriksons has presumably worked out rational arguments, and he indeed matches the landlord on most points; the landlord is especially troubled by the compliance of Andriksons' thinking to the logic of a debate.

More than that, in direct opposition to the landlord's vague attempt at reconciliation, the farmer refuses to accept a proposal which would fail to justify his deed of cutting down the trees. As the landlord tries to settle for a reasonable compromise, still keeping the upper hand, in a characteristic move he searches for a document to find out what the farmer should pay according to the going rate (which would mean not penalizing him). But the landlord cannot find a document which would legitimize his rights. This denial marks an unbridgeable psychological gap between the two and is clearly reflected in the switch of the landlord's relation towards the farmer. Searching for a formula for this switch, we could ask together with Walter Mignolo when he discusses the limits of the discourse of Western modernity, latent and/or manifest in the attitude toward this modernity's 'others': 'Who are you and who gave you right to say that about me?' (Mignolo 2011: 193).

What follows further in the novella is an even more complex elaboration of Andriksons' subconscious thoughts. For the sake of clarity, let me figure out three main facets of this process. Importantly, they are neither subsequent in their temporality nor clearly separated, but rather inextricably blended especially due to the personally disturbing discovery of the fact of Andriksons' missing children.

First, then, on his way home through the forest, Andriksons is still very much obsessed with the discourse of rationality exercised earlier and in which, as he feels, he almost succeeded, coming close to being able to match the landlord's argumentation; finally, however, he falls back into his colonial role of remaining almost the same - but not quite. He is overtaken by the sudden realization of the difference imposed by the coloniality of the landlord's power.

Next, the act of burning of the forest could work well as a substitute for any manifestation of savagery as constructed by the discourse of Western modernity. By this act, which can be interpreted as an anti-colonial challenge, Andriksons subconsciously appropriates the role of 'the other' bringing himself in direct opposition to the seemingly rational, Enlightenment-inspired rules of the game laid out by the landlord and his ancestors. 
And finally, in the most complex move, there is the issue of delinking from the world of binary oppositions created by the landlord's rules. In re-appropriating his own native sense of belonging to the land and, especially, to the landscape (land representing more an economic, and landscape more a cultural category), the farmer's experience of reality is now existentially juxtaposed to that of his social superior. What we notice here can be characterized by the shift away from the Western concept of Descartes' 'I think therefore I am' (think, we might add, according to the set rules of modernity/coloniality, characteristic of the landlord's world) to the decolonial option of individual choice summarized in the idea of 'I am where I do and think' which stresses the specificity of the locus of enunciation. Andriksons' regret points at a shifting geography of reason which, according to Nelson Maldonaldo-Torres, is part and parcel of the decolonial turn. (Maldonaldo-Torres 2011: 10)

In the last episode of the novella, we might want to rediscover the landlord, who has been instrumental in smothering the flames and, in addition, now brings Andriksons' children back to their troubled father, as an exemplary master figure of the rationality discourse of Western modernity. Still, on the brink of Andriksons' confession the landlord is left with the unavoidable feeling of the presence of the uncanny, or, in other words, with direct experience of the possible consequences of colonial practices, embedded in the darker side of his own (Western) modernity. The possibility of an anti-colonial revolt now lurks behind every encounter with 'the native'.

Andriksons, on the other hand, has run the full circle of modernity/(anti) coloniality/decoloniality, and under the circumstances finds himself pushed back to the discourse of rationality as a part of modernity which also means subordination to the distinction between that which is allowed and that which is disallowed and regulated by law. However, I want to argue that emphasis in Blaumanis' novella is put upon the possibility of delinking of one's world from that of colonial rules. For Andriksons, it is not an easy process, and it never could be; what we see in the novella, however, is the unavoidable point at which this move is ready to become unlocked, even if it turns out to be exactly as painful as it really is. At the deeper or secondary semiotic level, then, Blaumanis' novella signifies the overturning of the quasi-mythical structures of Western modernity imposed on other societies in the form of the colonial matrix of power which leaves no place for alternative developments.

To conclude, the novella provides us with a highly relevant example and an important marker in the writer's oeuvre and in what I would like to feature as his overall project of decoloniality. In my opinion, in his later works Blaumanis also gave his project its ultimate form, most significantly, in the play "Ugunï" 
KALNAČS

("In the Fire") $)^{2}$ which is beyond this paper's scope, but which further elaborates important motifs introduced in the discussion of the novella "Andriksons".

However, what may be seen as the fulfillment of one author's thought at a particular historical moment can only alert us to look more carefully toward our own realities. Delinking from both Western and, not less importantly, Eastern/Russian colonial discourses, imposed on our society, as well as overcoming closely related and deeply troubling manifestations of internal colonization and/or self-colonization which are the consequences of the earlier subaltern status, remain important issues in the process of substantiation of the Baltic identity in what might productively turn out, in the words of Walter Mignolo, the locally global context of the $21^{\text {st }}$ century.

\author{
Benedikts Kalnačs \\ benedikts.kalnacs@lulfmi.lv \\ Literatūras, folkloras un mākslas institūts \\ Latvijas Universitāte \\ Akadēmijas laukums 1 \\ LV-1050 Riga \\ LATVIJA
}

\title{
References
}

Blaumanis, R. 1958. Andriksons. - Kopoti raksti. Vol. 2. Rīga: Latvijas Valsts izdevniecība, 307-331.

Kalnačs, B. 2011. "Es atsakos no jūsu žēlastības, baronlielskungs.” Rūdolfa Blaumaņa novele "Andriksons": postkoloniāls lasījums. - Humanitāro Zinātñu Vēstnesis, 19, $17-22$.

Kalnačs, B. 2012. Smoke and Fire: Autoethnographic Expression In Early $20^{\text {th }}$ Century Latvian Literature. - http://www.otherness.dk/fileadmin/www.othernessandthearts.org/Publications/Journal_Otherness/Otherness_3.1new/Kalnacs.pdf

Maldonaldo-Torres, N. 2011. Thinking Through the Decolonial Turn: Post-continental Interventions in Theory, Philosophy, and Critique - An Introduction. - Transmodernity (Fall), 1-15.

Mignolo, W. 2011. The Darker Side of Western Modernity: Global Futures, Decolonial Options. Durham \& London: Duke University Press.

2 This text has been dealt with in my paper Smoke and Fire: Autoethnographic Expression In Early $20^{\text {th }}$ Century Latvian Literature (Kalnačs 2012). 